\title{
Understanding Islamic Values in Meaning of Work for Millennial Generation
}

Bella Anindya Karunisa, Olivia Fachrunnisa

To Link this Article: http://dx.doi.org/10.6007/IJARBSS/v11-i18/11431

DOI:10.6007/IJARBSS/v11-i18/11431

Received: 16 August 2021, Revised: 19 September 2021, Accepted: 28 September 2021

Published Online: 06 October 2021

In-Text Citation: (Karunisa \& Fachrunnisa, 2021)

To Cite this Article: Karunisa, B. A., \& Fachrunnisa, O. (2021). Understanding Islamic Values in Meaning of Work for Millennial Generation. International Journal of Academic Research in Business and Social Sciences, 11(18), 120-132.

Copyright: (C) 2021 The Author(s)

Published by Human Resource Management Academic Research Society (www.hrmars.com)

This article is published under the Creative Commons Attribution (CC BY 4.0) license. Anyone may reproduce, distribute, translate and create derivative works of this article (for both commercial and non-commercial purposes), subject to full attribution to the original publication and authors. The full terms of this license may be seen

at: http://creativecommons.org/licences/by/4.0/legalcode

Special Issue Title: TiBECVII 2021, 2021, Pg. 120 - 132

Full Terms \& Conditions of access and use can be found at http://hrmars.com/index.php/pages/detail/publication-ethics 


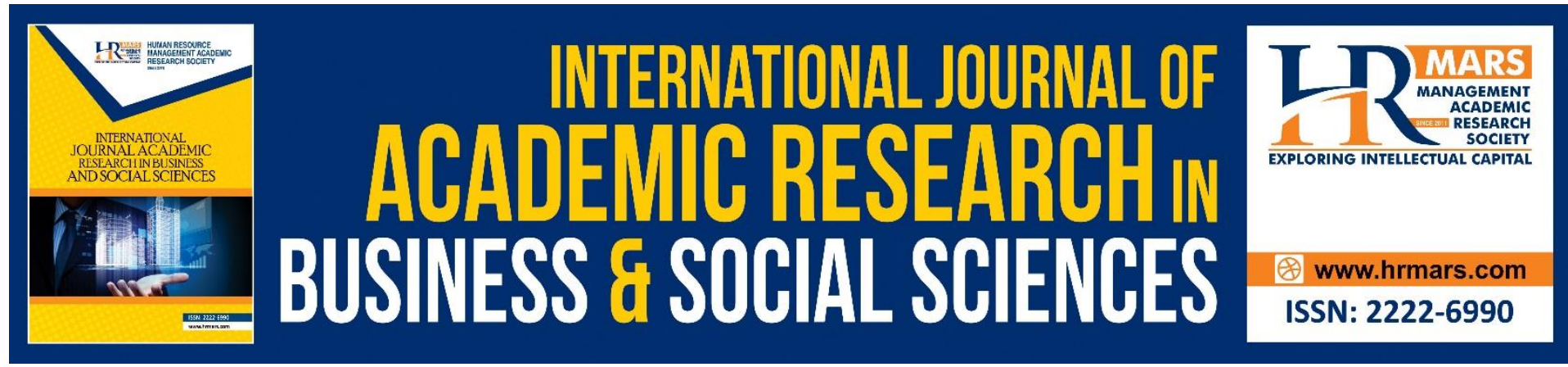

\title{
Understanding Islamic Values in Meaning of Work for Millennial Generation
}

\author{
Bella Anindya Karunisa, Olivia Fachrunnisa \\ Dept. of Management, Faculty of Economics, UNISSULA, Indonesia \\ Email: bellaanindyak@std.unissula.ac.id, olivia.fachrunnisa@unissula.ac.id
}

\begin{abstract}
The millennial generation is a generation that cannot be separated from technology in their lives. Almost all of his daily activities require digital assistance. This makes the millennial generation have a different view of life from previous generations, including a view on the meaning of work. Significance of this work is associated with the spirituality of Islamic work that existed at the millennial generation. The purpose of this research is to explore the meaning of work on the millennial generation based on an Islamic perspective. The research was conducted using qualitative methods and purposive sampling. The sample of this study comprised 20 students of the final semester at Islamic University in Semarang, Indonesia. The data were collected through observation, interviews also documentation, and using thematic analysis. The results indicated that the millennial work to fulfill the needs of life, worship, and self-actualization. The millennial described their job as bonding with the work institutions. They also work following Islamic principles and pursue the goal of the hereafter. In the long run, the millennial consider work should have a comfortable environment, ease them to perform worship and provide adequate facilities.
\end{abstract}

Keywords: Meaning of Work, Millennial Generation, Islamic Values, Job Description, Expectation at Work

\section{Introduction}

The meaning of work has been widely discussed in previous studies. Several studies have shown that the meaning of work across generations has several differences. This difference is caused by globalization, psychological and digital technology that continues to develop. In generations before millennial, they interpreted the meaning of work as welfare and financial independence, while in millennial the meaning of work was understood by choosing an organization based on working conditions, opportunities and flexibility offered (Ng et al., 2010). Known to have views and mindsets about life that are different from previous generations, millennial are often faced with important issues related to education and work. In preparing for the future, education is the main thing that is expected to be able to train someone to face the demands of the world and the wider community by balancing hard skills and soft skills. This will later have an impact on the needs of the millennial generation which is more about self-esteem and likes challenges. 
This fluctuating spirit makes the millennial generation not suitable if they work monotonously and want jobs that they feel have value and are very profitable for their survival. It can be realized by giving freedom and high flexibility to complete a job that is given (Martin, 2005). To fulfill the desires and involve the millennial generation in their work is quite a difficult task for a company. This can be overcome by utilizing existing resources by providing a supportive environment so as to increase the work of the millennial generation. In line with research Anitha \& Aruna (2016) that the millennial generation identifies more with the company's inner values, because the work value of the millennial generation is the most important and superior to loyalty to the company but wants a supportive work environment. Moreover, for the Muslim millennial generation, the meaning of work must also be based on Islamic provisions.

Makes the difference in the Muslim group regarding the understanding of the meaning of work in the millennial generation because of the Islamic principles they have. There have not been many studies that have tried to examine the internalization of Islamic values in the meaning of work for millennial Muslims. So this study aims to understand Islamic values in the meaning of work in the millennial generation. Starting from often found some companies pay less attention to the values of work spirituality. His absence resulted in limited and incomplete satisfaction of people within the company (Gotsis \& Kortezi, 2008). Judging from these problems, the company should pay more attention to spiritual values which are later expected to foster a sense of honesty, commitment, self-fulfillment and job satisfaction (Houghton et al., 2016). The previous research supports the belief that work spirituality in organizations will give positive results such as calmness, pleasure, and commitment (Fry, 2003; Giacalone \& Jurkiewicz, 2003; Reave, 2005). In the workplace, a person's spirituality contributes to a deeper and more meaningful understanding of work and reality in the company (Gotsis \& Kortezi, 2008). This will have an impact on the meaning of work for the millennial generation and be useful for HR Managers to facilitate the growth of the millennial workforce in increasing the meaning of work.

In Islamic principles, this life is not only oriented to the world but also to the hereafter, including work. Work is a worship that must be carried out because Islam itself explains that work is not only a fulfillment of needs but also upholds human dignity. The more knowledge about spirituality, the higher the value and dignity. So that Muslims in the world try to defend their faith as a way to assert their identity, face social injustice and as an alternative to fight hedonistic thinking (Hashim, 2009). In research Sulaiman \& Bhatti (2013) Islamic spirituality in an organizational context consists of four elements: worship, forgiveness ( $\left.A / a^{\prime} f w\right)$, faith, and the remembrance of Allah (dzikir). Islamic religious values are generally based on the principles of the Qur'an and Hadith (Sanders, 2009). So that religiously oriented values become strong and have an impact on the organization. This study discusses the meaning of work, job description and strategies to achieve work success in the Muslim millennial generation.

\section{Literature Review Meaning of Work}

The meaning of work is a set of values, beliefs, attitudes and expectations of a person in relation to work (Gaggiotti, 2006). According to Wiltshire (2016) the meaning of work in public work, namely (1) work to survive (2) routine activities (3) means of training skills (4) intrinsically satisfying activities (5) work as rewards (6) morally good work (7) meaningful experience and (8) activities gendered. From some of these definitions it can be concluded 
that the meaning of work is a personal resource that can interpret work in accordance with expectations and know the usefulness of work in order to increase work productivity. As for research according to Rosso et al (2010) there are various factors that influence the meaning of work with four main sources namely the self, others, the work context and spiritual life. In knowing the meaning of work, it can be seen through the expectations of that person. As for a person's expectations of his work can be distinguished based on the generation group. Millennial expectations about work according to $\mathrm{Ng}$ et al (2010) divided into five, namely work and life balance, good wages and benefits, meaningful work experience, opportunities for advancement and an educational work environment. So the organization must be able to understand the background and skills possessed by a worker in order to be able to read the expectations of a worker. By being able to read the expectations of what is desired, it will affect the meaning of work and make work productivity increase in accordance with the vision and mission of the organization.

\section{Millennial Generation Career Preparation}

Millennials are defined as digital natives who depend on technology and are instant in obtaining information and use technology a lot in their daily life to communicate (Black, 2010). Makes the millennial generation have different thoughts compared to previous generations and creates potential for creativity. Millennials also have a more open minded mind, this is influenced by several factors including the internet, electronics and social media that help the process globalization is faster. The millennial generation in preparing for their career can develop themselves with balanced soft skills and hard skills. Hard skills are more specific to certain types of activities or tasks, while soft skills can be applied broadly. Both hard skills and soft skills will produce the ability to prepare for a career. As for the anxiety that is often experienced by the millennial generation in preparing their careers. Anxiety is a common trait that often appears in a person. Especially when preparing for work to achieve work success. Factors that affect the anxiety experienced by students when entering the world of work include lack of soft skills, information about work, and confidence in one's own abilities. According to Campione (2016) many millennial generations leave their jobs before entering their three-year working period because they are less precise in finding the meaning of work so they feel uncomfortable with their work.

\section{Islamic Work Value}

Islamic sources are found in the Qur'an and Hadith, where it commands to do good and its qualities such as cleanliness, piety, wisdom, cooperation, consistency, equality, trust and worth living (Wahab et al., 2016). According to Rafiki \& Wahab (2014) some constructs of Islamic values as responsibility, honesty, punctuality and cooperation in accordance with the habits of the Prophet. The value of this Islamic context becomes one of the factors that influence the meaning of work built from the self. Ismail \& Badron (2012) explained that the Islamic framework was founded on reason as verification by revelation, so all policies in Islam are religiously oriented. As for Spilka et al (2003) spirituality is an aspect of life as an integrated system that clearly emphasizes the importance of values and practices to seek blessings and grace. Spiritual value is the application of spiritual values in the work environment based on the Qur'an and Sunnah related to islamic values, beliefs, and practices (Arslan, 2001). Spirituality is one of the most influential ways that are significantly related to employee attitudes, values, and behavior. Specifically the effect on the problems that exist in an organization including on the approaches and decisions of managers and employees. It can 
be concluded that the concept of policy in Islam has a good impact on individuals and their environment at work so as to make the organization more developed.

\section{Methodology}

This research belongs to "case study" Creswell (2016). The research was conducted by using qualitative methods and thematic analysis.

\section{Measures}

The technique of selecting respondents in this study was purposive sampling. The sample of this study comprised 20 students in the final semester from Islamic University in Semarang Indonesia. The data were collected by in-depth interviews. The data analysis used thematic analysis whose steps start from data reduction, data display, and conclusion. Data reduction is the process of selecting, focusing on simplification, and transforming the raw data from several records obtained from the field. The presentation of data is an activity when information is compiled so that it provides conclusions and action.

Table 1: Interview Guidance

\begin{tabular}{|c|c|c|}
\hline No & Research Question & Interviews \\
\hline 1 & The Meaning of Work & $\begin{array}{l}\text { a. What do you think of the } \\
\text { meaning of work? } \\
\text { b. Is work compulsory and what is } \\
\text { the reason? } \\
\text { c. What if you force yourself not to } \\
\text { work? } \\
\text { d. In the future, what is your reason } \\
\text { for choosing a job? }\end{array}$ \\
\hline 2 & Job description & $\begin{array}{l}\text { a. What is your perspective on } \\
\text { working in Islam? } \\
\text { b. How do you describe your work } \\
\text { in the future? } \\
\text { c. Does your job description } \\
\text { inspired by your parents. If it so, } \\
\text { why? } \\
\text { d. In the future, what are the } \\
\text { factors for anxiety at work? }\end{array}$ \\
\hline 3 & Expectation at work & $\begin{array}{l}\text { a. What is your motivation in } \\
\text { determining a job? } \\
\text { b. What are your expectation for } \\
\text { the work that you will enter? }\end{array}$ \\
\hline
\end{tabular}

\section{Results Analysis}

The respondents of this study were 20 students in the final semester of Islamic University in Semarang, Indonesia. Specifically, it consisted of 10 male respondents and 10 female respondents. During the in-depth interviews, no other person was involved and none of them was part of the human resource division which could influence their answer. 


\section{Muslim Millennial Generation in Meaning of Work}

The muslim millennial generation who are final semester students can interpret work for the future. There is a various interpretation of work.

When they graduate from university, they will look for a job that can help them in fulfilling their needs. It is because starting from a child they cannot be separated from the help and support of their parent. Thus they must be independent because later they will marry and have a family. It is obligatory to fulfill the needs of their family life. The results of the interview are depicted in the following transcripts:

"To fulfil my needs, right now, I still depend on my parents, I want to get married too, so my parents still help me. However, we have to work to earn our own money" (R14)

The muslim millennial generation works for worship. It has also been explained in QS. Jumu'ah verse 10: "Once the prayer is over, disperse throughout the land and seek the bounty of Allah. And remember Allah often so you may be successful". Meanwhile, the result of the interview is as follows:

"Yes, work is like worship because we know that we live in this world not only to worship such as prayer but to work too" (R17)

It is also explained that as a man it is obligatory to earn a living. A man will become the head of the family in life when he is married.

"In the world of work we are also men who are the backbone of our family. In Islam we are required to provide for our wives and children as well as make our parents happy" (R5)

The female respondent interpreted work as self-actualization. Working is their highest achievement in life and can develop their selves with pleasure.

"I think work is an activity if I define work as a hobby" (R4)

\section{The Perspective of the Obligation of Millennial Generation on Work}

From male Muslim millennial, they think that work is mandatory, which is stated in the QS. An-Nisa verse 34 states "Men are the caretakers of women, as men have been provisioned by Allah over women and tasked with supporting them financially". The interview excerpt is as follows:

"In my opinion, work is compulsory. It's the duty of men to make a living" (R13)

The female Muslim millennial argued that work may be compulsory for them because in life they must be independent and as much as possible not dependent on other people.

"It is mandatory because we cannot depend on our parents only. We also have our own lives, so we have to work rather than to be troublesome" (R1)

Work may also not be compulsory for those whose needs have been fulfilled from an early age. It is a condition where they have been born rich. So that their money is enough to fulfill all the needs of life.

"It is not mandatory, for example the son of the Sultan, the money is really sufficient and yes you want to work, what do you expect from your work in fact you already had it all " (R7)

\section{There is a State of Compulsion not to Work}

In urgent circumstances work is number one. It is because technological developments work in any condition. There is no reason not to work.

"Yes, work but based on our abilities. For example, sleeping, we basically have to work, take advantage of the cell phone like that, even though we can't wake up we can work selling online" (R11) 
There are also situations where not to work is not a problem, because everyone has the capacity and needs of each other than work.

"You can push yourself because everyone has their own capacity" (R16)

\section{Reasons for Choosing a Job after Graduating from University}

In choosing a job, the millennial will choose according to their abilities. This ability is in accordance with their major. With their abilities, they hope they can work optimally.

"We have to do our best with the capabilities we have and the company gives the best for us too" (R10)

We have to understand that the respondents chose a job also by paying attention to Islamic sharia in the company. As a good muslim, you have to think of it.

"My principle is that you must stick to religion, avoiding immorality, and distance yourself from usury" (R12)

\section{Muslims Millennial Perspective Work in Islam}

Working in Islam has long-term goals. The hereafter becomes the final destination. By working according to Islamic sharia, we must have a full responsibility and sincerity and obey religious orders. The respondent explained as follows:

"I work not only to think of worldly things but also think of the hereafter, because every deed is recorded by Allah SWT through the Raqib and Atid" (R16)

Besides that, honesty is also an important point in working. Honesty is meant to be honest in words and deeds. Be honest not only with others but also honest with yourself.

"We work honestly and to be trusted" (R5)

\section{Future Job Description}

Some muslim millennials who became the respondents wanted a job that is under contract by an agency. Working tied to an agency is a guarantee at the beginning of starting a career because it can increase career paths in the company by maximizing work so that it has a good reputation for its performance.

"Working in a company, of course, can have a better career, if you have a career, you will have all of your prayers, you can rest easy" (R10)

Some respondents also want to become entrepreneurs. Being an entrepreneur will be more flexible in managing time. The business can provide jobs for other people so that it helps reduce unemployment in Indonesia.

"Of course my dream is to have a business, have employees, I oblige these employees to pray dhuha, if it's prayer time, I let them pray" (R3)

\section{Inspirational Job Description}

Many job descriptions of muslim millennials are inspired by their parents. It is derived from their parent's job and responsibility in fuffilling the needs of their family.

"Yes, it was inspired by my parents because since I was a child, they have shown me how they interact" (R20)

"In terms of hard work, it is inspired to be even more active at work" (R15)

Inspiration also comes from yourself. Lessons and experiences inspire the muslim millennial to have job description of these two things,

"Actually not, my family is more into civil servant entrepreneurs too, but the term civil servants are not as free as entrepreneurs" (R17) 


\section{Anxiety while Working Later}

External factors become one of the concerns when you are in the world of work. There is anxiety beyond one's control.

"In terms of competitors, for example, friends have better skills, so we feel inferior" (R3)

"I'm afraid that during work there are things that are prohibited by religion but are allowed to do at work" (R19)

There are internal factors that make anxious. This factor is a fear in Muslim millennial when they have a job description. Including the following:

"My anxiety is what is, in terms of my skills, I think it's not really maximal" (R2)

\section{Motivation in Determining Work}

In determining a work, many muslim millenials are motivated by inspirational figures. They imitate and explore their ability based on abilities and experience of inspirational figures characters.

"The exact motivation for parents is from parents and also for parents" (R6)

"The inspirational figure is Prophet Muhammad. The prophet Muhammad was honest in trading; he continued to work hard too" (R15)

"It's more like a person, so he's a psychologist" (R7)

In determining their job, some muslim millennial want to be human beings that are beneficial to others. Giving benefits for others can also increase a person's degree.

"The motivation of every person is not only for their selves but has a sense also for the decision that if we can live, it has to be useful for others" (R13)

\section{Hope for the World of Work}

Muslim millennials want a comfortable work environment. A supportive environment can provide comfort and tranquillity when completing work.

"Environmental factors also influence us. It is because if we are not comfortable we cannot focus" (R14)

Do not forget that muslim millennial hopes to get a job that can make him obedient to religion. It is realized by not neglecting God's orders and staying away from God's prohibitions.

"In accordance with Islam we must think of the world and the hereafter as well" (R5)

Adequate and contemporary facilities are also the hope of muslim millennials. Proper facilities they can complete the work maximally which is expected to give good feedback to the company.

"I hope to be in a fun work environment because millennial generation likes to be happy. The company is such as Start-up Company. It spoils their employees, not putting employees under pressure" (R16) 


\section{Discussion}

\section{The Meaning of Work}

\section{THE MEANING OF WORK}

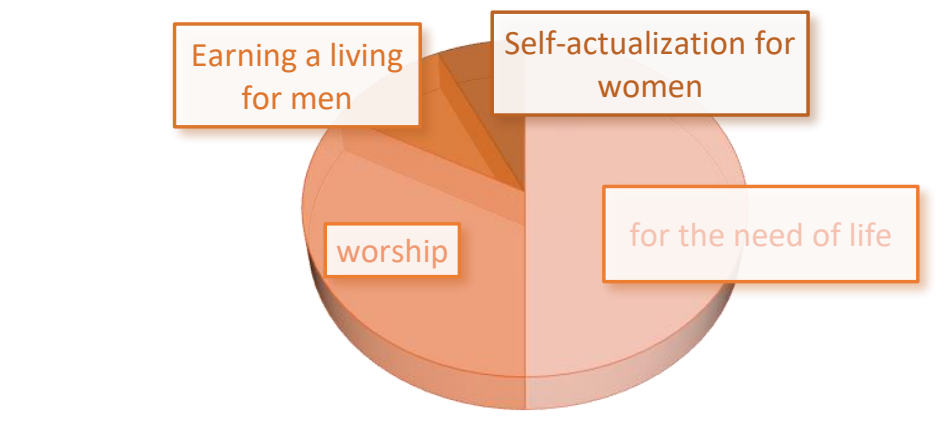

Figure 1: The Meaning of Work from Muslim Millennial

The millennial generation has its own perspective in interpreting work. According to Rosso et al (2010), various factors affect the meaning of work. They are individual, people, work context, and spiritual life. From the results of this study, it is affirmed that millennial Muslims interpret work for the needs of life, worship, earning a living for men, and self-actualization for women.

In a study by $\mathrm{Ng}$ et al (2010), the millennial generation has more expectations more than salary and income. However, from the results of this study, the millennial generation only wants independent life so they don't depend on other people, especially their parents. By working, they hope to repay their parents' kindness that has been given to them. They also consider working as worship. Furthermore Ismail \& Badron (2012), explained that the Islamic framework is established based on its correlation with religion. According to this research, muslim millennial at work are religious-oriented where the purpose of working is worship. Thus they must adhere to Islamic principles. It is realized by doing the job honestly, not neglecting religious orders, and only hoping for the pleasure of Allah.

This study also found the meaning of work based on gender. Men defined working as an obligation to earn a living because later they get married and have a family that becomes their responsibility. Meanwhile, women defined working as self-actualization where they work according to what they like and can express themselves. The understanding of muslim millennials about work is inseparable from their reasons for choosing a job. They pay attention to their abilities, passion and following Islamic principles. 


\section{Job Description}

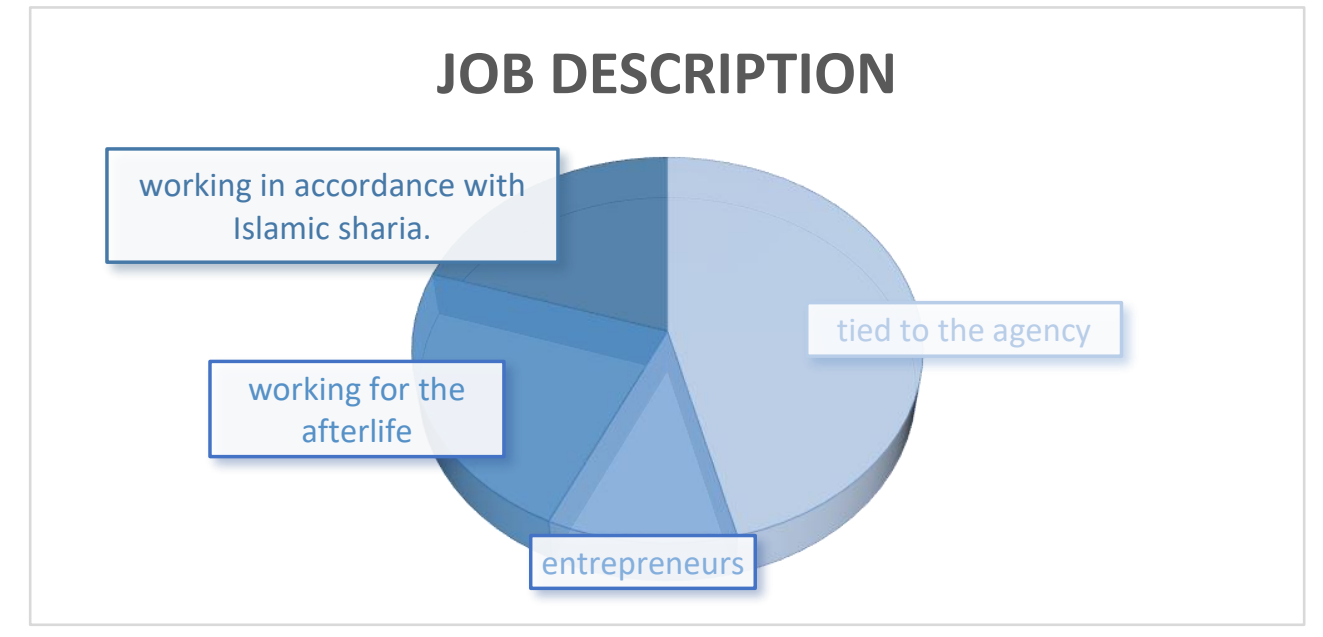

Figure 2: Job Description

In this research, we found four acceptable job descriptions in the future; some want to work under contract with an agency and some of them want to be entrepreneurs. It cannot be separated from the role of parents and factors that need to be considered in choosing a job. In addition, they also want to work under Islamic principle to pursue the afterlife.

Working is not only to fulfill the needs and desires in the world but as provisions for later in the hereafter. Having the goal of working for the afterlife makes muslim millennials more careful and thorough in sorting out a job. As the result, their job is following Islamic principles. As a good muslim millennial, this is their dream future work while still seeing and applying for work from an Islamic perspective. As found in the research of Spilka et al (2003), it is explained that spirituality is an aspect of life as an integrated system that clearly emphasizes the importance of its values and practices to seek blessings and mercy.

A person's spirituality in the organization will improve the work performance and involvement so that it can help the organization to continue to develop and compete in the world of work. However, muslim millennials have external and internal worries in thinking about future jobs. It includes increasingly fierce competition. They also worry about their abilities and skills at work. This anxiety makes muslim millennials want to continue to improve their quality so that they can achieve their dream job.

\section{Expectation in the World of Work}

\section{EXPECTATION IN THE WORLD OF WORK}

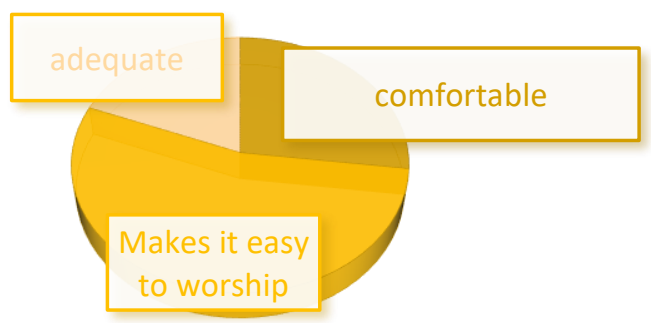

Figure 3: Expectation in the World of Work 
According to Wendlandt \& Rochlen (2008), school to work transitions can be successfully navigated through three different phases. It is marked by information gathering and evaluation, which leads to the formation of work expectations. It is an adaptation process where individuals enter new organizations and environments that give broader insight. The last is an achievement, individuals recognize their position, whether they want to continue working in the organization or not. Through work expectations, muslim millennial hope they will have a comfortable work environment that supports their performance. It aims to make them complete work happily and with enthusiasm. This will give satisfactory results for both individuals and the company. In this way, it is expected that this comfortable environment will ease them to perform worship as a fulfillment of individual needs with God.

Muslim millennials expect that when they are in the world of work, the job will ease them to perform worship. For them, work does not only focus on the world but the hereafter is also a priority that will shape the construct of Islamic values. The research of Rafiki \& Wahab (2014) indicates that some constructs of Islamic values as responsibility, honesty, timeliness, and cooperation under the habits of the Prophet. Muslim millennials expect adequate facilities because this can increase their work productivity. This adequate facility is in the form of training that can improve skills, sophisticated technology, a workplace that is not monotonous and there is a strategic and comfortable place to worship.

The expectations cannot be separated from what motivates them in determining a job. The motivations for millennial Muslims include parents, the behavior of the Prophet Muhammad who is very noble and exemplary, and someone successful at work. These three things motivate Muslim millennial work to benefit others.

\section{Conclusion and Recommendation}

The formulation of the problem in this study is how does the muslim millennial generation interpret the expected work. The result indicated that the meaning of work for the muslim millennial generation is a work to fulfill the needs of life, and it can be seen from the gender side that men work to earn a living and women work in order to actualize themselves. Where in interpreting the work of the muslim millennial generation, they have a job description for the future. The job description that the muslim millennial generation wants job as bonding with the work institutions. They also work following Islamic principles and pursue the goal of the hereafter. With the description of the desired job, the muslim millennial generations have expectations at work. The expectations of the millennial consider work should have a comfortable environment, ease them to perform worship and provide adequate facilities.

The results of the study provide recommendations to the leader of a company. The managerial recommendations or implications that can be proposed are as follows companies are expected to better understand muslim millennial employees in interpreting a job. The muslim millennial generation does not only chase salary but also comfort when working. They also wish to have a job with flexible time, good co-workers, and company regulations that do not neglect the Islamic principles. As the result, they will get a comfortable environment to develop themselves and contribute to the company development and companies are expected to pay attention to facilities for millennial employees by providing adequate facilities, a modern and not monotonous concept. For the muslim millennial generation, they have a job description that when they work they want a modern workspace so they can work comfortably, get training that can develop themselves and there are space and time where muslim millennial can perform worship on time with a strategic place of worship. 


\section{References}

Anitha, J., \& Aruna, M. (2016). Enablers of Employee Engagement of Gen $Y$ at the Workplace with reference to Automobile Sector. Amity Journal of Training and Development, 1(1), 93-108.

Arslan, M. (2001). The work ethic values of Protestant British, Catholic Irish and Muslim Turkish managers. Journal of Business Ethics, 31(4), 321-339.

Black, A. (2010). Gen Y: Who They Are and How They Learn. Educational Horizons, 88(2), 92101.

Campione, W. A. (2016). Volunteer Work Experience: Can It Help Millennials to Find Meaning and Interest in their Work and to Negotiate their Role Within the Workplace? Journal of Leadership, Accountability and Ethics, 13(3), 11.

Creswell, J. W. (2016). Research Design: Qualitative, Quantitative and Mixed Methods Approach (Fourth). SAGE Publication, Inc.

Fry, L. W. (2003). Toward a theory of spiritual leadership. Leadership Quarterly, 14(6), 693727.

Gaggiotti, H. (2006). Going from Spain and Latin America to Central Asia : decision-making of expatriation and meaning of work. The Central Asia Business Journal, 1(November), 1.

Giacalone, R. A., \& Jurkiewicz, C. L. (2003). Right from Wrong: The Influence of Spirituality on Perceptions of Unethical Business Activities. Journal of Business Ethics, 46(1), 8597.

Gotsis, G., \& Kortezi, Z. (2008). Philosophical foundations of workplace spirituality: A critical approach. Journal of Business Ethics, 78(4), 575-600.

Hashim, J. (2009). International Journal of Islamic and Middle Eastern Finance and Management Islamic revival in human resource management practices among selected Islamic organisations in Malaysia. International Journal of Islamic and Middle Eastern Finance and Management Asia-Pacific Journal of Business Administration Iss Personnel Review Iss Personnel Review, 2(6), 251-267.

Houghton, J. D., Neck, C. P., \& Krishnakumar, S. (2016). The what, why, and how of spirituality in the workplace revisited: a 14-year update and extension. Journal of Management, Spirituality and Religion, 13(3), 177-205.

Ismail, M. Z., \& Badron, M. S. (2012). Good Governance - Adab-Oriented Tadbir in Islam. IKIM.

Martin, C. A. (2005). From high maintenance to high productivity: What managers need to know about Generation Y. Industrial and Commercial Training, 37(1), 39-44.

Ng, E. S. W., Schweitzer, L., \& Lyons, S. T. (2010). New generation, great expectations: A field study of the millennial generation. Journal of Business and Psychology, 25(2), 281-292.

Rafiki, A., \& Wahab, K. A. (2014). Islamic values and principles in the organization: A review of literature. Asian Social Science, 10(9), 1-7.

Reave, L. (2005). Spiritual values and practices related to leadership effectiveness. Leadership Quarterly, 16(5), 655-687.

Rosso, B. D., Dekas, K. H., \& Wrzesniewski, A. (2010). On the meaning of work: A theoretical integration and review. Research in Organizational Behavior, 30(C), 91-127.

Sanders, J. A. (2009). The Book of Job and the origins of Judaism. Biblical Theology Bulletin, $39(2), 60-70$.

Spilka, B., Hood, R. W., \& Hill, P. C. (2003). The psychology of religion: An empirical approach. The Guilford Press.

Sulaiman, M., \& Bhatti, O. K. (2013). Workplace deviance and spirituality in Muslim 
organizations. Asian Social Science, 9(10), 237-246.

Wahab, M. A., Quazi, A., \& Blackman, D. (2016). Measuring and validating Islamic work value constructs: An empirical exploration using Malaysian samples. Journal of Business Research, 69(10), 4194-4204.

Wendlandt, N. M., \& Rochlen, A. B. (2008). Addressing the college-to-Work transition: Implications for university career counselors. Journal of Career Development, 35(2), 151-165.

Wiltshire, A. H. (2016). The meanings of work in a public work scheme in South Africa. International Journal of Sociology and Social Policy, 36(1-2), 2-17. 